\title{
Electrical conductivity test in the evaluation of the physiological potential of treated and stored soybean seeds
}

\section{Teste de condutividade elétrica na avaliação do potencial fisiológico de sementes de soja tratadas e armazenadas}

\author{
Ana Paula Silva Couto ${ }^{1 *}$; Cristian Rafael Brzezinski2; Julia Abati ${ }^{3}$; Ronan Carlos \\ Colombo4; Fernando Augusto Henning ${ }^{5}$; Inês Cristina de Batista Fonseca6; \\ Claudemir Zucareli ${ }^{6}$
}

\section{Highlights}

Storage and chemical treatment influences physiological quality of soybean seeds.

The electrical conductivity test correlates with other vigor tests.

Electrical conductivity is effective in classifying treated soybean seeds for vigor.

\section{Abstract}

Soybean seed treatment contributes to the maintenance of seed quality, but the effect of commercial formulations and chemical products on the effectiveness of the electrical conductivity test based on electrolyte leaching has been frequently questioned. This study aimed to verify the interference of the chemical seed treatment of two soybean cultivars on the effectiveness of the electrical conductivity test in evaluating the vigor of freshly treated and stored seeds. The experimental design was completely randomized, consisting of seven seed treatments and two evaluation periods ( 0 and 60 days after storage), with four replications. The used seed treatments consisted of 1) fipronil + pyraclostrobin + thiophanatemethyl, 2) imidacloprid + thiodicarb + carbendazim + thiram, 3) abamectin + thiamethoxan + fludioxonil

1 PhD Student in Agronomy, Graduate Program in Agronomy, Center for Agricultural Sciences, Universidade Estadual de Londrina, UEL, Londrina, PR, Brazil. E-mail: anapaula_couto@live.com

2 Nursery Manager, GDM Seeds, Palmas, TO, Brazil. E-mail: cbrzezinski@gdmseeds

${ }^{3} \mathrm{PhD}$ in Agronomy, Department of Agronomy, Center for Agricultural Sciences, UEL, Londrina, PR, Brazil. E-mail: juliaabati@yahoo.com.br

${ }^{4}$ Prof. Dr., Department of Agricultural Sciences, Universidade Tecnológica Federal do Paraná, UTFPR, Linha Santa Bárbara, Francisco Beltrão, PR, Brazil. E-mail: ronancolombo@utfpr.edu.br

${ }^{5}$ Researcher, Empresa Brasileira de Pesquisa Agropecuária, EMBRAPA Soja, Londrina, PR, Brazil. E-mail: fernando. henning@embrapa.br

${ }^{6}$ Profs. Drs., Department of Agronomy, Center for Agricultural Sciences, UEL, Londrina, PR, Brazil. E-mail: inescbf@ uel.br; claudemircca@uel.br

* Author for correspondence

Received: Mar. 10, 2021 - Approved: July 23, 2021 
+ mefenoxam + thiabendazole, 4) carbendazim + thiram, 5) fludioxonil + mefenoxam + thiabendazole, 6) carboxin + thiram, and 7) control (no treatment). The cultivars were BRS 360 RR and BRS 284, which were analyzed separately. Germination, accelerated aging, emergence, and electrical conductivity tests were carried out. No differences were detected between the control and chemical treatments performed on seeds of the two freshly treated soybean cultivars regarding germination, accelerated aging, and emergence tests. The germination test stood out after storage with the cultivar BRS 360 RR, showing the maintenance of germination potential for seeds treated with carbendazim + thiram and the control treatment. Therefore, the chemical treatment of soybean seeds interferes with the result of the electrical conductivity test. The electrical conductivity test is effective in segregating seed lots in terms of vigor level. The electrical conductivity test correlates with the other vigor tests used to identify the reduction in the physiological seed quality with storage.

Key words: Glycine max (L.) Merrill. Ion leaching. Quality control. Vigor test.

\section{Resumo}

O tratamento de sementes de soja contribui na manutenção da qualidade das sementes, entretanto, o efeito de formulações e produtos químicos comerciais sobrea eficácia do teste de condutividade elétrica, baseado na lixiviação de eletrólitos, é algo de contínuos questionamentos. Objetivou-se verificar a interferência do tratamento químico de sementes de duas cultivares de soja sobre a eficácia do teste de condutividade elétrica em avaliar o vigor das sementes recém tratadas e armazenadas. O delineamento experimental foi inteiramente casualizado, com quatro repetições, sendo sete tratamentos de sementes e dois períodos de avaliação (0 e 60 dias após o armazenamento). Os tratamentos de sementes utilizados foram: 1 ) fipronil + piraclostrobina + tiofanato metílico; 2) imidacloprido + tiodicarbe + carbendazim + thiram; 3) abamectina + tiametoxan + fludioxonil + mefenoxam + thiabendazole; 4) carbendazim + thiram; 5) fludioxonil + mefenoxam + thiabendazole; 6) carboxin + thiram e 7) tratamento controle (sem tratamento). As cultivares foram BRS 360 RR e BRS 284, analisadas separadamente. Realizaram-se os testes de germinação, envelhecimento acelerado, emergência em areia e condutividade elétrica. Não foram detectadas diferenças entre os tratamentos controle e químicos realizados nas sementes das duas cultivares de soja recém tratadas nos testes de germinação, envelhecimento acelerado e emergência em areia. Após o armazenamento, destacase o teste de germinação com a cultivar BRS 360 RR, em que a manutenção do potencial de germinação foi observada para as sementes tratadas com carbendazim + thiram e tratamento controle. Conclui-se que o tratamento químico de sementes de soja interfere no resultado do teste de condutividade elétrica. $\mathrm{O}$ teste de condutividade elétrica apresenta eficácia em segregar os lotes de sementes quanto ao nível de vigor. $\mathrm{O}$ teste de condutividade elétrica correlaciona-se com os demais testes de vigor utilizados para identificar a redução da qualidade fisiológica de sementes com o armazenamento.

Palavras-chave: Controle de qualidade. Glycine max (L.) Merrill. Lixiviação de íons. Teste de vigor.

\section{Introduction}

The use of high physiological, physical, sanitary, and genetic quality seeds is necessary for the crop to have the desired stand and vigorous seedlings, contributing to achieving high yield levels (Krzyzanowski, França-Neto, \& Henning, 2018). 
Seed chemical treatment with insecticides, fungicides, and other additives such as micronutrients and growth promoters, whether before storage or sowing, contributes to maintaining seed quality and obtaining plant stand in the field. However, studies have shown that the chemical treatment of soybean seeds in periods long before sowing can reduce their physiological quality and harm initial establishment, as well as crop yield (Brzezinski et al., 2015; Pereira et al., 2018).

Moreover, the Ministry of Agriculture, Livestock and Food Supply of Brazil (Ministério da Agricultura, Pecuária e Abastecimento [MAPA], 2013) sets standards for the production and marketing of soybean seeds, which must have at least $80 \%$ germination and $99 \%$ physical purity. However, in addition to germination, several other tests can be used to determine the vigor of soybean seeds, including the electrical conductivity test (Krzyzanowski et al., 2018).

The electrical conductivity test has been efficiently used to assess the vigor of soybean seeds due to its ease of execution, low cost, speed, reproducibility, and easy interpretation of results (Avelar, 2021; Prado, Krzyzanowski, Martins, \& Vieira, 2019; Ramos, Matos, Martins, \& Martins, 2012). The principle of the test is directly related to the integrity of cell membranes, as the test determines the amount of leachate present in the seed soaking solution. Thus, the lower the release of exudates in the solution, the higher the seed vigor, that is, the lesser the disorganization of cell membrane systems (Marcos, 2015; Silva, Zambiasi, Tilmann, Menezes, \& Villela, 2014).

However, according to Vieira and Marcos (2020), some seed analysts still have doubts about the convenience of conducting the electrical conductivity test on treated seed samples. Also, the authors mention the need for studies to clarify whether these products can affect the test results. Moreover, new formulations and chemical products have been introduced in the market. Aguilera, Caron, Cella and Lersh (2000) and Bittencourt, Fernandes, Ribeiro and Vieira (2000) observed that corn seeds treated with fungicides and/ or insecticides presented higher values of electrical conductivity than untreated seeds, which could compromise the test effectiveness in estimating the physiological potential, with no correlation with the behavior during storage or under field conditions.

On the other hand, Aveling, Govender, Kandolo and Kritzinger (2012) and Vazquez, Cardoso and Peres (2014) found that corn seeds treated with fungicides and insecticides showed no difference in the electrolyte leakage compared to untreated seeds. Similar results have been found by other authors when evaluating pea seeds with fungicides (Silva, Freitas, \& Nascimento, 2013) and soybean seeds treated with fungicides and insecticides (Costa, Nunes, Ventura, Arantes, \& Mendes, 2018).

The influence of chemical products such as fungicides and insecticides used in treated and stored soybean seeds on the results and effectiveness of the electrical conductivity test is still incipient, mainly considering the increase in use and quantity and diversity of active ingredients in the industrial seed treatment.

Thus, this study aimed to verify the interference of the seed treatment of two soybean cultivars with different commercial chemical products on the effectiveness of the electrical conductivity test in evaluating the vigor of freshly treated and stored seeds. 


\section{Material and Methods}

The experiment was carried out at the Technological Nucleus of Seeds and Grains of the Brazilian Agricultural Research Corporation, Embrapa Soja, Londrina, PR, Brazil, at the Laboratories of Seed Physiology and Technology. The experimental design was completely randomized in a $7 \times 2$ factorial scheme, with four replications. The factors consisted of seven soybean seed treatments with commercial chemical products recommended for the crop (Table 1) and two evaluation periods during storage ( 0 and 60 days).

\section{Table 1}

Active ingredients, commercial chemical products, and doses used in different chemical treatments of soybean seeds of the cultivars BRS 360 RR and BRS 284

\begin{tabular}{|c|c|c|c|c|c|}
\hline Treatment & Active ingredient (ai) & $\begin{array}{l}\text { Commercial } \\
\text { name }\end{array}$ & Type $^{1}$ & $\begin{array}{l}\text { Commercial } \\
\text { product dose }\end{array}$ & Water dose ${ }^{3}$ \\
\hline 1 & $\begin{array}{c}\text { Fipronil + } \\
\text { pyraclostrobin }+ \\
\text { thiophanate-methyl }\end{array}$ & Standak Top ${ }^{\circledR}$ & $I+F+F$ & 200 & 400 \\
\hline 2 & $\begin{array}{c}\text { Imidacloprid } \\
+ \text { thiodicarb }+ \\
\text { carbendazim + thiram }\end{array}$ & $\begin{array}{c}\text { Cropstar }^{\circledast}+ \\
\text { Derosal Plus }^{\circledR}\end{array}$ & $I+I+F+F$ & $300+200$ & 100 \\
\hline 3 & $\begin{array}{l}\text { Abamectin + } \\
\text { thiamethoxam } \\
+ \text { fludioxonil + } \\
\text { mefenoxam + } \\
\text { thiabendazole }\end{array}$ & $\begin{array}{c}\text { Avicta } \\
\text { Completo } \\
\text { (Avicta } 500 \mathrm{FS}^{\circledast} \\
+ \text { Cruiser }^{\circledR} 350 \\
\text { FS + Maxim } \\
\text { Advanced }^{\oplus} \text { ) }\end{array}$ & $N+I+F+F+F$ & $200+125+100$ & 175 \\
\hline 4 & Carbendazim + thiram & Derosal Plus ${ }^{\circledR}$ & $F+F$ & 200 & 400 \\
\hline 5 & $\begin{array}{c}\text { Fludioxonil + } \\
\text { mefenoxam + } \\
\text { thiabendazole }\end{array}$ & $\begin{array}{c}\text { Maxim } \\
\text { Advanced }^{\circledR}\end{array}$ & $F+F+F$ & 100 & 500 \\
\hline 6 & Carboxin + thiram & $\begin{array}{c}\text { Vitavax-Thiram } \\
200 \text { SC }^{\circledR}\end{array}$ & $F+F$ & 250 & 350 \\
\hline 7 & Control treatment & - & - & - & - \\
\hline
\end{tabular}

The soybean cultivars were BRS 360 RR and BRS 284, analyzed separately. The cultivar BRS 360 RR is genetically modified to tolerate the herbicide glyphosate, with an indeterminate growth habit and maturity group 6.2. The cultivar BRS 284 is conventional, with an indeterminate growth habit and maturity group 6.3. The seed lot selection for each 
cultivar was determined according to the results obtained in the tetrazolium test to verify the seed vigor and viability, aiming to obtain lots with similar initial quality and within the commercialization standards of the species.

The tetrazolium test was carried out with 50 seeds per replication, being preconditioned in germitest paper moistened with distilled water for $16 \mathrm{~h}$ in a germinator at $25{ }^{\circ} \mathrm{C}$. Subsequently, the seeds were submerged in tetrazolium solution (2,3,5-triphenyltetrazolium chloride) at a concentration of $0.075 \%$ and maintained at a temperature of $40{ }^{\circ} \mathrm{C}$ for approximately 150 minutes inside a germination chamber in the absence of light. The seeds were then individually evaluated and classified according to the criteria proposed by França-Neto and Krzyzanowski (2018). The cultivars BRS 360 RR and BRS 284 presented vigor of 93 and $92 \%$ and viability of 99 and $98 \%$, respectively.

Product doses were defined before carrying out the chemical treatment, with a maximum spray solution volume of $600 \mathrm{~mL} 100$ $\mathrm{kg}^{-1}$ seeds. Seed treatment was carried out in polyethylene bags. The spray solutions with the products were added using disposable syringes and the bags were vigorously shaken to distribute evenly the spray solution over the seeds, which remained exposed for a period of one hour at room temperature to allow drying. Then, the samples were placed in cardboard boxes and stored for 60 days under uncontrolled environmental conditions, which corresponds to the conditions of most of the structures used in seed storage.

The following tests were performed in each evaluation period:

Germination: performed with two subsamples of 50 seeds per replication, totaling 400 seeds per treatment. The seeds were placed on germitest paper rolls moistened with distilled water at an amount of 2.5 times the substrate dry mass. The paper rolls were placed in a germinator at $25^{\circ} \mathrm{C}$. The evaluations were carried out according to the Rules for Seed Testing (MAPA, 2009), with results expressed in the percentage of normal seedlings.

Accelerated aging: the seeds were placed in incubator plastic boxes (gerbox) with a screen, containing $40 \mathrm{~mL}$ of water at the bottom, forming a uniform layer on the screen surface, and maintained in an incubator at $41{ }^{\circ} \mathrm{C}$ for $48 \mathrm{~h}$ (Marcos, 2020). Then, the germination test was performed according to the Rules for Seed Testing (MAPA, 2009), with two subsamples of 50 seeds per replication, totaling 400 seeds per treatment.

Seedling emergence in sand: 400 seeds were used per treatment, divided into a subsample of 100 seeds per replication. The seeds were sown in plastic trays containing sand and stored in a greenhouse. Moisture was maintained by irrigation as required by the seedlings. The final number of emerged normal seedlings was counted on the 10th day and the results were expressed as a percentage.

Electrical conductivity: the mass conductivity method was carried out using 50 seeds per replication, totaling 200 seeds per treatment. After obtaining the mass of each sample on a digital scale with an accuracy of $0.0001 \mathrm{~g}$, the seeds were placed in plastic cups containing $75 \mathrm{~mL}$ of deionized water and taken to a germination chamber at a constant temperature of $25^{\circ} \mathrm{C}$ for $24 \mathrm{~h}$ (Vieira \& Marcos, 2020). The electrical conductivity of the seed soaking solution was determined at the end of this period using a DM-32 ${ }^{\circledR}$ digital 
bench conductivity meter. The results were expressed in $\mu \mathrm{S} \mathrm{cm}^{-1} \mathrm{~g}^{-1}$.

The data were analyzed for normality and homoscedasticity using the Shapiro-Wilk and Hartley tests, respectively, which indicated no need for transformation. Analysis of variance was performed, and the means were compared using the Scott-Knott test at the $5 \%$ probability error. The statistical program SISVAR version 5.6 (Ferreira, 2011) was used in the analyses. In addition, Pearson's simple correlation analysis $(r)$ was also conducted at 1 and $5 \%$ probability error between the evaluated traits using the R software through the cor.test function of the stats package $(R$ Core Team [R], 2019).

\section{Results and Discussion}

Table 2 shows a significant interaction between the factors chemical treatments and evaluation periods for germination and electrical conductivity for the cultivar BRS $360 \mathrm{RR}$. The factors treatment and periods were significant in isolation for accelerated aging, with a significant effect for the factor periods for emergence in sand. The cultivar BRS 284 showed no significant effects for the interaction between the factors treatments and periods in all evaluated traits. In isolation, germination was significantly altered by the factors treatments and periods, while accelerated aging, emergence in sand, and electrical conductivity were altered only by the factor of evaluation periods.

\section{Table 2}

Analysis of variance (mean squares) for physiological quality traits evaluated in two soybean cultivars (BRS 360 RR and BRS 284) in response to chemical seed treatment and evaluation periods (0 and 60 days of storage)

\begin{tabular}{|c|c|c|c|c|}
\hline \multicolumn{5}{|c|}{ BRS 360 RR } \\
\hline SV & G & $\mathrm{AA}$ & EMS & CE \\
\hline Treatment (T) & 16.23 ** & 254.35 ** & $0.70 \mathrm{~ns}$ & 154.77 * \\
\hline Period (P) & 247.71 ** & 2720.09 ** & 5.00 * & 18650.32 ** \\
\hline $\mathrm{T} \times \mathrm{P}$ & 8.39 * & $24.06 \mathrm{~ns}$ & $0.54 \mathrm{~ns}$ & $158.37^{*}$ \\
\hline Error & 3.05 & 34.66 & 0.98 & 50.48 \\
\hline CV (\%) & 1.86 & 7.29 & 1.01 & 10.30 \\
\hline Mean & 93.97 & 80.76 & 97.79 & 68.99 \\
\hline \multicolumn{5}{|c|}{ BRS 284} \\
\hline SV & G & AA & EMS & CE \\
\hline Treatment (T) & 94.49 * & $107.91 \mathrm{~ns}$ & $6.02 \mathrm{~ns}$ & 740.76 ns \\
\hline Period (P) & 1360.02 ** & $18448.57^{* *}$ & 40.02 ** & 68778.76 ** \\
\hline $\mathrm{T} \times \mathrm{P}$ & $49.24 \mathrm{~ns}$ & $29.59 \mathrm{~ns}$ & $10.69 \mathrm{~ns}$ & $174.06 \mathrm{~ns}$ \\
\hline Error & 32.79 & 45.10 & 4.48 & 343.29 \\
\hline CV (\%) & 7.26 & 15.38 & 2.36 & 16.27 \\
\hline Mean & 78.90 & 43.67 & 89.83 & 113.90 \\
\hline
\end{tabular}

ns not significant, ${ }^{*}$ significant at $5 \%$, and ${ }^{* *}$ significant at $1 \%$ probability error by the $\mathrm{F}$-test.

SV: source of variation; T: treatment; P: storage period; G: Germination; AA: accelerated aging; EMS: emergency in sand; EC: electrical conductivity. 
The slicing of the interaction between the factors chemical treatments and evaluation periods showed a reduction in seed germination after 60 days of storage for all evaluated treatments in the cultivar BRS 360 RR (Table 3). However, the percentage of germination in all treatments was within the standards for the production and marketing of soybean seeds in the two evaluation periods ( 0 and 60 days), which is at least $80 \%$ (MAPA, 2013). The chemical treatment showed no influence on seed germination at 0 days of storage, while treatment 4 (carbendazim + thiram) and control resulted in higher germination than the other treatments at 60 days.

\section{Table 3}

Physiological seed quality of two soybean cultivars (BRS 360 RR and BRS 284) in response to chemical treatment and evaluation periods ( 0 and 60 days of storage)

\begin{tabular}{|c|c|c|c|c|c|c|}
\hline \multirow[b]{4}{*}{ Treatment $^{1}$} & \multicolumn{3}{|c|}{ BRS 360 RR } & \multicolumn{3}{|c|}{ BRS 284} \\
\hline & \multicolumn{6}{|c|}{ Germination (\%) } \\
\hline & \multicolumn{2}{|c|}{ Period } & \multicolumn{4}{|c|}{ Period } \\
\hline & 0 & 60 & Mean & 0 & 60 & Mean \\
\hline 1 & $95.5 \mathrm{Aa}$ & $92.0 \mathrm{Bb}$ & 93.7 & 85.6 & 73.3 & $79.5 \mathrm{~b}$ \\
\hline 2 & $96.1 \mathrm{Aa}$ & $90.1 \mathrm{Bb}$ & 93.1 & 84.8 & 64.1 & $74.5 \mathrm{~b}$ \\
\hline 3 & 94.6 Aa & $90.3 \mathrm{Bb}$ & 92.5 & 83.5 & 73.5 & $78.5 \mathrm{~b}$ \\
\hline 4 & 97.3 Aa & $93.5 \mathrm{Ba}$ & 95.4 & 85.0 & 82.0 & $83.5 \mathrm{a}$ \\
\hline 5 & 97.0 Aa & 88.3 Bb & 92.6 & 86.5 & 70.8 & $78.6 \mathrm{~b}$ \\
\hline 6 & $96.5 \mathrm{Aa}$ & $90.1 \mathrm{Bb}$ & 93.3 & 79.1 & 68.1 & $73.6 \mathrm{~b}$ \\
\hline 7 & 97.6 Aa & $96.4 \mathrm{Ba}$ & 97.0 & 87.5 & 80.5 & $84.0 \mathrm{a}$ \\
\hline Mean & 96.4 & 91.5 & & $84.5 \mathrm{~A}$ & $73.2 \mathrm{~B}$ & \\
\hline \multirow[t]{3}{*}{ CV (\%) } & & 1.8 & & & 7.2 & \\
\hline & \multicolumn{6}{|c|}{ Accelerated aging (\%) } \\
\hline & \multicolumn{2}{|c|}{ Period } & \multicolumn{4}{|c|}{ Period } \\
\hline Treatment $^{1}$ & 0 & 60 & Mean & 0 & 60 & Mean \\
\hline 1 & 88.3 & 75.8 & $82.0 \mathrm{~b}$ & 65.8 & 19.5 & $42.6 \mathrm{a}$ \\
\hline 2 & 79.0 & 62.3 & $70.6 \mathrm{c}$ & 65.5 & 19.1 & $42.3 \mathrm{a}$ \\
\hline 3 & 83.5 & 67.6 & $75.5 \mathrm{c}$ & 62.1 & 16.5 & $39.3 \mathrm{a}$ \\
\hline 4 & 94.4 & 83.6 & $89.0 \mathrm{a}$ & 72.6 & 30.3 & $51.5 \mathrm{a}$ \\
\hline 5 & 91.0 & 71.8 & $81.4 b$ & 57.5 & 21.0 & $39.2 \mathrm{a}$ \\
\hline 6 & 90.0 & 67.3 & $78.6 \mathrm{c}$ & 63.2 & 27.0 & $45.1 \mathrm{a}$ \\
\hline 7 & 95.5 & 80.3 & $87.9 a$ & 65.5 & 25.5 & $45.5 \mathrm{a}$ \\
\hline Mean & $88.8 \mathrm{~A}$ & 72.7 B & & $64.6 \mathrm{~A}$ & $22.7 \mathrm{~B}$ & \\
\hline CV (\%) & & 7.2 & & & 15.3 & \\
\hline
\end{tabular}

continue... 
contuation...

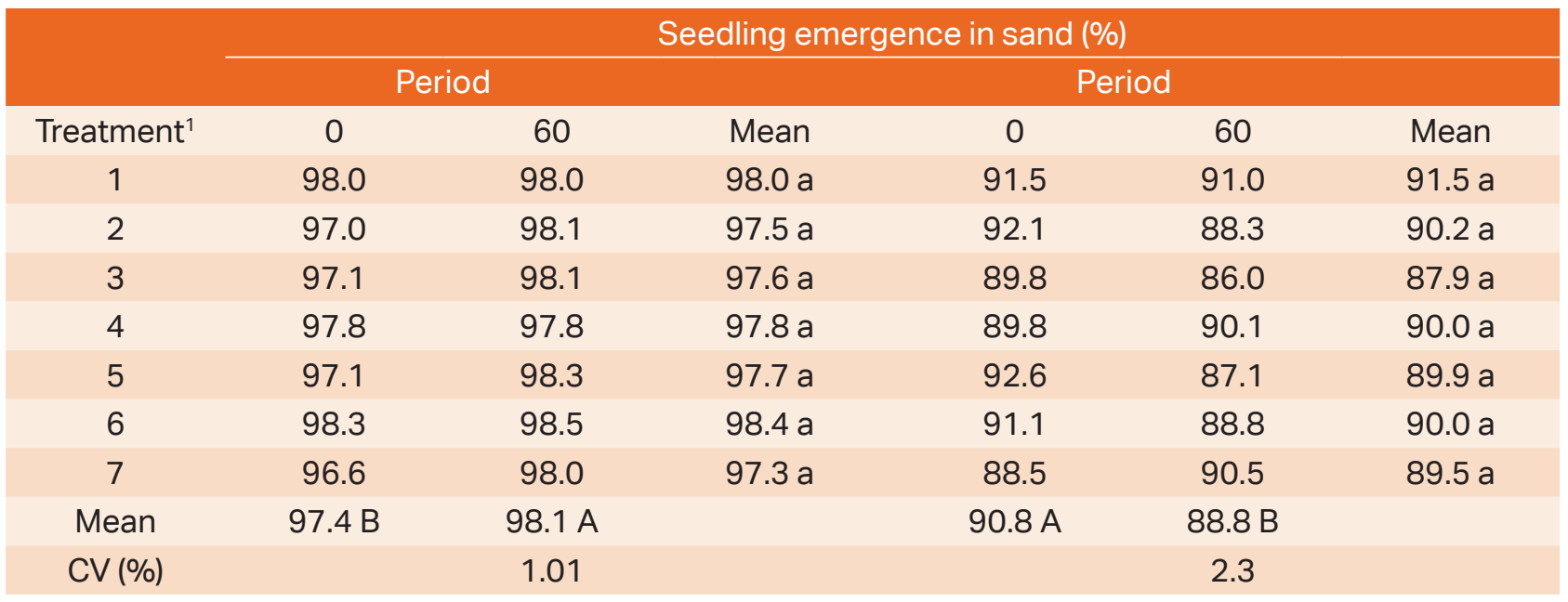

Means followed by the same uppercase letter in the row for periods and lowercase letter in the column for treatment effects do not differ from each other by the F-test and Scott-Knott test, respectively, at $5 \%$ probability error.

${ }^{1}$ Treatments: 1: fipronil + pyraclostrobin + thiophanate-methyl; 2: imidacloprid + thiodicarb + carbendazim + thiram; 3: abamectin + thiamethoxan + fludioxonil + mefenoxam + thiabendazole; 4: carbendazim + thiram; 5 : fludioxonil + mefenoxam + thiabendazole; 6: carboxin + thiram; 7 : control (no treatment).

The cultivar BRS 284 also showed a reduction in germination after 60 days of storage, but only treatment 6 (carboxin + thiram) did not reach the minimum percentage of germination at zero days of storage, as recommended by MAPA (2013) (Table 3). A more expressive reduction in seed germination was observed at 60 days, with only treatment 4 (carbendazim + thiram) and control remaining within the minimum standards.

These results indicate a possible toxic effect on the seeds treated with chemical products, as seed germination reduced in treatments $1,2,3,5$, and 6 compared to the control after 60 days of storage in both cultivars. A study conducted with the soybean cultivars NA 4823RG, BMX Turbo RR, and Fundacep 62RR showed that the seed treatment with chemical products, including the fungicide carbendazim + thiram and the insecticide imidacloprid + thiodicarb, which were also active ingredients used in the present studies in treatments 2 and 4 , did not affect seed germination during the 60 days of storage (Conceição et al., 2016). Therefore, it is important to evaluate these results according to each cultivar.

The accelerated aging test provides information about seed storage potential and seedling emergence in the field. Both cultivars showed a reduction in seed germination after 60 days of storage for this trait (Table 3), with treatment 4 (carbendazim + thiram) and control presenting a higher percentage of germination than the other treatments for the cultivar BRS 360 RR. The cultivar BRS 284 showed no differences between chemical treatments and control according to the evaluation periods. 
The reduction in physiological seed quality over time observed by germination and accelerated aging tests in seeds from the control treatment and with commercial chemical products occurs due to deterioration processes. This process consists of the natural aging of seeds in a progressive and irreversible rhythm, culminating in their death, being this process aggravated when they are stored under environmental conditions (Marcos, 2015), observed in both cultivars in the present study. Also, the deterioration rate is more intensified when seeds are exposed to the conditions of the accelerated aging test, that is, high temperature and relative humidity, as these environmental factors present the highest influence on the deterioration speed.

The cultivar BRS 360 RR showed an increase in the percentage of seedling emergence in sand after storage for 60 days, with values close to $100 \%$ at 0 and 60 days, demonstrating that the seeds maintained high vigor even when treated and stored. On the other hand, the cultivar BRS 284 showed a reduction in seedling emergence at 60 days of storage compared to 0 days.
The more significant reduction in the germination potential of seeds of the cultivar BRS 284 compared to the cultivar BRS 360 may be associated with genetic differences between both cultivars, the previous history of the used seed lot, including the management adopted in its production field, and weather conditions during the crop cycle (Carvalho \& Nakagawa, 2012). Other studies carried out with untreated soybean seeds of transgenic and conventional cultivars have shown a genetic difference between cultivars regarding the reduction in the physiological quality during storage for 180 (Ávila et al., 2011) and 210 days (Carvalho, Coelho, \& Souza, 2014).

Electrical conductivity (Table 4) showed an interaction between the factors periods and treatments in the cultivar BRS $360 \mathrm{RR}$, with an increase of $87.8 \%$ in the amount of electrolytes after 60 days of seed storage. As previously discussed, seeds go through the deterioration process over time, thus presenting higher disorganization of membrane systems, with the greater release of electrolytes, which are quantified by the electrical conductivity test (Marcos, 2015). 
Table 4

Electrical conductivity ( $\mu \mathrm{S} \mathrm{cm}^{-1} \mathrm{~g}^{-1}$ ) of seeds from two soybean cultivars (BRS $360 \mathrm{RR}$ and BRS 284) in response to chemical treatment and evaluation periods ( 0 and 60 days of storage)

\begin{tabular}{ccccccc} 
& \multicolumn{5}{c}{ BRS 360 RR } \\
\cline { 2 - 7 } & \multicolumn{7}{c}{ Period } & \multicolumn{5}{c}{ BRS 284 } \\
\cline { 2 - 7 } Treatment $^{1}$ & 0 & 60 & Mean & 0 & 60 & Mean \\
\hline 1 & $54.6 \mathrm{Ba}$ & $90.6 \mathrm{Aa}$ & 72.6 & 87.3 & 172.0 & $129.7 \mathrm{a}$ \\
2 & $37.8 \mathrm{Bb}$ & $95.2 \mathrm{Aa}$ & 66.5 & 65.9 & 140.2 & $103.1 \mathrm{a}$ \\
3 & $43.0 \mathrm{Bb}$ & $80.2 \mathrm{Ab}$ & 61.6 & 63.6 & 148.7 & $106.1 \mathrm{a}$ \\
4 & $42.8 \mathrm{Bb}$ & $84.9 \mathrm{Ab}$ & 63.9 & 84.4 & 162.6 & $123.5 \mathrm{a}$ \\
5 & $58.9 \mathrm{Ba}$ & $84.8 \mathrm{Ab}$ & 71.9 & 61.9 & 145.5 & $103.7 \mathrm{a}$ \\
6 & $51.9 \mathrm{Ba}$ & $99.4 \mathrm{Aa}$ & 75.7 & 59.1 & 156.8 & $107.9 \mathrm{a}$ \\
7 & $46.0 \mathrm{Bb}$ & $95.0 \mathrm{Aa}$ & 70.5 & 91.5 & 154.5 & $123.0 \mathrm{a}$ \\
Mean & 47.9 & 90.0 & & $73.4 \mathrm{~B}$ & $154.3 \mathrm{~A}$ & \\
CV (\%) & & 10.3 & & & 16.2 &
\end{tabular}

Means followed by the same uppercase letter in the row for periods and lowercase letter in the column for treatment effects do not differ from each other by the F-test and Scott-Knott test, respectively, at 5\% probability error.

1Treatments: 1: fipronil + pyraclostrobin + thiophanate-methyl; 2: imidacloprid + thiodicarb + carbendazim + thiram; 3: abamectin + thiamethoxan + fludioxonil + mefenoxam + thiabendazole; 4: carbendazim + thiram; 5: fludioxonil + mefenoxam + thiabendazole; 6: carboxin + thiram; 7: control (no treatment).

The previous analyses showed that treated and untreated seeds of the cultivar BRS 360 RR had similar initial physiological quality. Therefore, chemical treatments 2, 3, and 4 did not interfere with the effectiveness of the electrical conductivity test at 0 days of storage, that is, freshly treated seeds, as they presented values similar to the control treatment. However, treatments 1, 5, and 6 presented electrical conductivity values higher than the control treatment, which is an indication that the composition of these products may influence the results of this test.

The test carried out with this cultivar after 60 days of storage showed that the control and treatments 1, 2, and 6 did not differ from each other, showing the lowest vigor levels evaluated by the electrical conductivity test, while treatments 3,4 , and 5 presented the best vigor levels. Thus, the chemical treatments did not influence the test accuracy, and treatments 3,4 , and 5 maintained seeds with better quality.

Corn seeds treated with insecticides (fipronil + pyraclostrobin + thiophanate-methyl, imidacloprid + thiodicarb, thiamethoxan, fipronil, pirimiphos-methyl, deltamethrin, and bifenthrin) and fungicides (fludioxonil + metalaxyl-M, and captan) showed no influence on chemical treatments for the electrical conductivity test when stored for 35 days (Vazquez et al., 2014). On the other hand, Vanzolini, Martinelli-Seneme and Silva (2006) treated soybean seeds with micronutrients and found an increase in electrical conductivity of the seed soaking solution, but without interfering with the lot classification by vigor. It demonstrates the importance of investigating 
the effects of different products in this test according to each crop.

The cultivar BRS 284 presented an effect only for the factor period (Table 4), with an increase of $110.2 \%$ in the electrical conductivity as the storage period increased. Furthermore, no differences were observed between treatments, but no influence of chemical treatments was observed on the results of this test at 0 and 60 days of storage.

Prado et al. (2019) suggested a vigor classification according to the electrical conductivity (EC) values to identify the field performance potential of seeds from different soybean seed lots: very high vigor $(E C \leq 70 \mu S$ $\mathrm{cm}^{-1} \mathrm{~g}^{-1}$ ), high vigor (EC between 71 and $90 \mu \mathrm{S}$ $\mathrm{cm}^{-1} \mathrm{~g}^{-1}$ ), and medium vigor (EC between 91 and $110 \mu \mathrm{S} \mathrm{cm}^{-1} \mathrm{~g}^{-1}$ ).

Thus, considering the vigor classification proposed by Prado et al. (2019), seeds of the cultivar BRS 360 RR from all chemical treatments and control presented a very high vigor at 0 days of storage, while seeds from treatments 3,4 , and 5 presented a high vigor and treatments $1,2,6$, and 7 showed a medium vigor at 60 days after storage.

Similarly, considering the vigor classification proposed by Prado et al. (2019), seeds of the cultivar BRS 284 from treatments
$2,3,5$, and 6 could be classified as very high vigor at 0 days of storage, treatments 1 and 4 as high vigor and the control treatment as medium vigor. All chemical treatments showed a low vigor at 60 days after storage.

Still considering the vigor classification proposed by Prado et al. (2019), Carvalho et al. (2014) observed that the cultivar BRS 284 had the highest values of electrical conductivity after storage $\left(108 \mu \mathrm{S} \mathrm{cm} \mathrm{cm}^{-1} \mathrm{~g}^{-1}\right)$, showing the shorter longevity and physiological quality than the other evaluated genotypes (EC between 54.8 and $86.2 \mu \mathrm{S} \mathrm{cm}^{-1} \mathrm{~g}^{-1}$ ), corroborating with the results obtained in this study.

According to Prado et al. (2019), a very high vigor indicates a good seed performance in the field under low soil moisture conditions, a medium vigor indicates that the seeds are unsuitable for sowing under water deficit conditions, and low vigor indicates that the seeds are not viable for sowing.

The Pearson's linear correlation ( $r$ ) analysis of the cultivars BRS 360 RR and BRS 284 and the storage periods ( 0 and 60 days) was performed together (Table 5 ) to broadly understand the effectiveness of the electrical conductivity test compared to the other analyzed vigor tests (accelerated aging and emergence in sand) and the germination test.

\section{Table 5}

Pearson's simple correlation coefficients ( $r$ ) estimated between the electrical conductivity (EC), germination (G), accelerated aging (AA), and seedling emergence in sand (EMS) tests

$\begin{array}{ccccc} & \text { EC } & \text { EMS } & \text { AA } & \text { G } \\ \text { G } & -0.73 & 0.74 & 0.86 & - \\ \text { AA } & -0.85 & 0.74 & - & - \\ \text { EMS } & -0.54 & - & - & -\end{array}$

Significant at $1 \%$ probability error by the F-test. 
A significant $(p<0.01)$ and negative correlation were observed between the electrical conductivity and all other traits (Table 5). Therefore, the seeds showed a reduction in the percentage of germination and seedling emergence with an increase in the amount of electrolytes, verified by the electrical conductivity test, that is, the values were inversely proportional. The results of the electrical conductivity test showed a strong negative correlation for the accelerated aging $(r=-0.85)$ and germination tests $(-0.73)$ and a moderate correlation for the emergence test $(r=-0.54)$.

The results show a decrease in the germination capacity over time even when the seeds present a high physiological quality at the beginning of storage. Therefore, in addition to the germination test, other tests such as the vigor test are a viable alternative for characterizing the physiological quality of different seed lots, including the electrical conductivity test, which correlated with the other tests and presents the advantage of being an alternative of easy execution, low cost speed, practicality, and easy interpretation of results (Avelar, 2021; Ramos et al., 2012; Vieira \& Marcos, 2020).

Moreover, the test was efficient in classifying the seed vigor level according to the initial characterization despite the interference of chemical treatments on the electrical conductivity of seeds. Therefore, its use is a possibility compared to the treatments used in this study. Although all the advantages provided by this test, changes in products (active ingredients), quantities, and forms of application will require further studies to prove the non-interference of the chemical treatment on its effectiveness, including the evaluation of this effect in a higher number of soybean cultivars, transgenic or not.

\section{Conclusions}

The chemical treatment of soybean seeds can interfere with the result of the electrical conductivity test, but it does not change its effectiveness in segregating soybean seed lots of the cultivars BRS 360 RR and BRS 284 regarding the vigor level. Furthermore, it correlates with the other vigor tests used to identify the reduction in the physiological quality of stored seeds.

\section{Acknowledgments}

To the National Council for Scientific and Technological Development (CNPq) for granting the scholarship to the first author. The State University of Londrina and the Brazilian Agricultural Research Corporation, National Soybean Research Center (Embrapa Soybean) for providing the facilities and financial support for the development of this research.

\section{References}

Aguilera, L. A., Caron, B. O., Cella, W. L., \& Lersh, I., Jr. (2000). Qualidade fisiológica de sementes de milho em função da forma e do tratamento químico das sementes. Ciência Rural, 30(2), 211-215. doi: 10. 1590/S0103-84782000000200003

Avelar, S. A. G. (2021). Teste de condutividade elétrica para avaliação do vigor de sementes de soja. Revista Seeds News, 25(1), 46-47. 
Aveling, T. A. S., Govender, V., Kandolo, D. S., \& Kritzinger, Q. (2012). The effects of treatments with selected pesticides on viability and vigour of maize (Zea mays) seeds and seedling emergence in the presence of Fusarium graminearum. Journal of Agricultural Science, 151(4), 474-481. doi: 10.1017/S002185961200 0457

Ávila, M. R., Braccini, A. de L., Albrecht, L. P., Scapim, C. A., Mandarino, J. M. G., Bazo, G. L., \& Cabral, Y. C. F. (2011). Effect of storage period on isoflavone content and physiological quality of conventional and transgenic soybean seeds. Revista Brasileira de Sementes, 33(1), 149-161. doi: 10.1590/S0101-312 22011000100017

Bittencourt, S. R. M., Fernandes, M. A., Ribeiro, M. C., \& Vieira, R. D. (2000). Desempenho de sementes de milho tratadas com inseticidas sistêmicos. Revista Brasileira de Sementes, 22(2), 86-93.

Brzezinski, C. R., Henning, A. A., Abati, J., Henning, F. A., França-Neto, J. de B., Krzyzanowski, F. C., \& Zucareli, C. (2015). Seeds treatment times in the establishment and yield performance of soybean crops. Journal of Seed Science, 37(2), 147-153. doi: 10.1590/2317-1545 v37n2148363

Carvalho, C. F., Coelho, C. M. M., \& Souza, C. A. (2014). Qualidade de sementes de soja submetidas ao armazenamento no oeste de Santa Catarina, Brasil. Revista Engenharia na Agricultura, 22(4), 287293. doi: 10.13083/reveng.v22i4

Carvalho, N. M., \& Nakagawa, J. (2012). Sementes: ciência, tecnologia e produção (5a ed.). Jaboticabal: FUNEP.
Conceição, G. M., Lúcio, A. D., Mertz-Henning, L. M., Henning, F. A., Beche, M., \& Andrade, F. F. (2016). Physiological and sanitary quality of soybean seeds under different chemical treatments during storage. Revista Brasileira de Engenharia Agrícola e Ambiental, 20(11), 10201024. doi: 10.1590/1807-1929/agriambi. v20n11p1020-1024

Costa, E. M., Nunes, B. M., Ventura, M. V. A., Arantes, B. H. T., \& Mendes, G. R. (2018). Efeito fisiológico de inseticidas e fungicida sobre a germinação e vigor de sementes de soja (Glycine max L.). Científic@, 5(2), 77-84. doi: 10. 29247/2358-260X.2018v5i2

Ferreira, D. F. (2011). SISVAR: a computer statistical analysis system. Ciência e Agrotecnologia, 35(6), 1039-1042. doi: 10.1590/S1413-70542011000600001

França-Neto, J. de B., \& Krzyzanowski, F. C. (2018). Metodologia do teste de tetrazólio em sementes de soja. (Documentos, 406). Londrina: EMBRAPA CNPSo.

Krzyzanowski, F. C., França-Neto, J. de B., \& Henning, A. A. (2018). A alta qualidade da semente de soja: fator importante para a produção da cultura. EMBRAPA Soja. (Circular Técnica, 136). Londrina: EMBRAPA Soja.

Marcos, J., Fo. (2020). Teste de envelhecimento acelerado. In F. C. Krzyzanowski, R. D. Vieira, J. de B. França-Neto, \& J. Marcos, $F^{\circ}$. (Eds.), Vigor de sementes: conceitos e testes (Cap. 4, pp. 185-246). Londrina: ABRATES.

Marcos, J., Fo. (2015). Fisiologia de sementes de plantas cultivadas (2a ed.). Londrina: ABRATES. 
Ministério da Agricultura, Pecuária e Abastecimento (2013). Instrução Normativa $n^{\circ}$ 45, 402 de 17 de setembro de 2013: Anexo XXIII. Brasília: D.O.U, p. 38.

Ministério da Agricultura, Pecuária e Abastecimento (2009). Regras para análise de sementes. Brasília: MAPA-ACS. 399p.

Pereira, L. C., Garcia, M. M., Braccini, A. L., Ferri, G. C., Suzukawa, A. K., Marteli, D. C. V., \& Matera, T. C. (2018). Physiological potential of soybean seeds over storage after industrial treatment. Journal of Seed Science, 40(3), 272-280. doi: 10. 1590/2317-1545v40n3185104

Prado, J. P. do, Krzyzanowski, F. C., Martins, C. C., \& Vieira, R. D. (2019). Physiological potential of soybean seeds and its relationship to electrical conductivity 1. Journal of Seed Science, 41(4), 407-415. doi: 10.1590/2317-1545v41n4214988

R Core Team (2019). R: a language and environment for statistical computing. Vienna, Austria: R Foundation for Statistical Computing.

Ramos, K. M. O., Matos, J. M. M., Martins, R. C. C., \& Martins, I. S. (2012). Electrical conductivity testing as applied to the assessment of freshly collected Kielmeyera coriacea Mart. seeds. International Scholarly Research Network, 2012, 1-5. doi: 10.5402/2012/378139
Silva, P. P., Freitas, R. A., \& Nascimento, W. M. (2013). Pea seed treatment for Rhizoctonia solani control. Journal of Seed Science, 35(1), 17-20. doi: 10.1590/ S2317-15372013000100002

Silva, V. N., Zambiasi, C. A., Tilmann, M. A. A., Menezes, N. L., \& Villela, F. A. (2014). Condução do teste de condutividade elétrica utilizando partes de sementes de feijão. Revista de Ciências Agrárias, 37(2), 206-213. doi: 10.19084/rca.16816

Vanzolini, S., Martinelli-Seneme, A., \& Silva, M. A. da. (2006). Teste de condutividade elétrica em sementes de soja tratadas com micronutrientes. Ceres, 53(309), 590-596.

Vazquez, G. H., Cardoso, R. D., \& Peres, A. R. (2014). Tratamento químico de sementes de milho e o teste de condutividade elétrica. Bioscience Journal, 30(3), 773781.

Vieira, R. D., \& Marcos, J., Fo. (2020). Teste de condutividade elétrica. In F. C. Krzyzanowski, R. D. Vieira, J. de B. FrançaNeto, \& J. Marcos, Fo. (Eds.), Vigor de sementes: conceitos e testes (Cap. 8, pp. 333-375). Londrina: ABRATES. 